\title{
Metaphor as a Means of Pessimism in English Poetry
}

\author{
Mohamed Ayed Ibrahim Ayassrah ${ }^{1} \&$ Ali Odeh Alidmat ${ }^{1}$ \\ ${ }^{1}$ Department of Basic Science, Balqa' Applied University, Aqaba, Jordan \\ Correspondence: Mohamed Ayed Ibrahim Ayassrah, Department of Basic Science, Balqa' Applied University, \\ Aqaba, Jordan. E-mail: Ayasrah@gmail.com or abuyazeed1977@yahoo.com
}

Received: April 22, 2017 Accepted: May 22, 2017 Online Published: July 26, 2017

doi:10.5539/ijel.v7n5p135 URL: http://doi.org/10.5539/ijel.v7n5p135

\begin{abstract}
The present study attempts to investigate using metaphor as a powerful tool of pessimism in poetic texts with special emphasis on T.S Eliot's Waste Land. Eliot's Waste Land which is heavily pregnant of metaphors is a great epic poetic story summarizes the gloomy circumstances of the European life after the World War I where a complexity of sad feelings dominates the whole five parts of the poem. Eliot vividly used metaphor as an effective means in transferring the real degradation of the European life after the Great War.

This study includes an introduction, significance of the study, choosing the metaphorical pessimistic expressions in Eliot's Waste Land, questions of the study, objectives of the study, methodology, what is metaphor? functions of metaphor, what is pessimism? The Waste Land, Eliot's life, why was Eliot pessimist in his great Waste Land? the analysis session, the answers of the study questions and the references.
\end{abstract}

Keywords: pessimism, metaphor, optimism

\section{Introduction}

Literature generally and poetry particularly are not only means of flirtation, gratification, pleasure or eloquence, but they also mirror real circumstances of societies. Indeed they are like the living creatures which are affected by the outside environment. Definitely, what affects society is illustrated in literature; what is seen pessimistic in literature is not more than the real negativity of the society itself. This study aims to investigate the metaphorical pessimistic expressions in T.S Eliot's The Waste Land which is considered as an attempt of representing the European tragic life from Eliot's point of view after the World War I. Besides, the study sheds light on depicting the cultural and spiritual death of the modern society using metaphorical expressions.

It also throws light on the significance of metaphor for poets as a rhetorical tool helping them to play with words, meanings and so scenes making them clearer, more effective and more attractive. However, poetry is taken as the field of the study because it is full of the aesthetic expressions, especially rhetorical ones. Also, it is found that poetry, among all literary genres, is the richest field of metaphorical occurrences, where a short poem may have more metaphorical expressions than a newspaper, a novel or even a play.

In much different veins at recent annals of literature, some other considerable studies have also been conducted in Metaphor and Grammatical Metaphor to lexicogrammatically and semantically investigate various texts and discourses to discern multiple strategies exploited by orators and authors in political, scientific, religious etc. texts to make the texts persuasive, significant, appealing and obscure as well (Cap \&Okulska, 2013; Kazemian et al., 2013; Kazemian \& Hashemi, 2014; Noor et al., 2015; Zhou \& Kazemian, 2015; Kazemian \& Hashemi, 2017). Prior studies have tended to concentrate on some other genres and discourses. This study is unique in the sense that it attempts to bridge the gap among previous studies by Analyzing Metaphor as a Means of Pessimism in English Poetry.

\subsection{Significance of the Study}

Although many researches and papers on metaphors are available, this study is, to the best of the researcher's knowledge, the first that investigates metaphor as a means of pessimism in T.S Eliot's "The Waste Land". Furthermore, this research aspires to contribute to the field of research on global studies of metaphors. Moreover, it throws light on the significance of using metaphor in pessimistic poetry. Besides, it throws light on using metaphor as a means of pessimism in English poetry. 


\subsection{Choosing the Metaphorical Pessimistic Expressions in Eliot's Waste Land as the Material Study}

Pessimism in poetry is chosen to be the scope of this study since poetry has been a rich field of studying such issue due to its deep relationship to the real life of the community besides the life of the poet himself. More specifically, the pessimistic style used by T.S. Eliot in his poem The Waste Land will be the main concern of this study. The Waste Land represents a reflection of the miserable life of the European community, particularly during and after the World War I. Furthermore, dealing with The Waste Land is an additional credit for dedicating time and effort for this topic.

\subsection{Questions of the Study}

The present study raises, and hopes to answer, the following questions:

1). Does Eliot use metaphor as a means of pessimism.

2). Is metaphor an effective rhetorical factor in constructing popular pessimistic poems as The Waste Land?

3). How frequent are metaphorical expressions used in The Waste Land?

\subsection{Objectives of the Study}

The study intends to achieve the following objectives:

a. Highlighting the issue of metaphor in T.S. Eliot's The Waste Land'.

b. Highlighting pessimism in T.S. Eliot's The Waste Land'.

c. Highlighting metaphor as a means of pessimistic expression used by T.S Eliot.

d. To show that the destruction of the European civilization is rhetorically illustrated in T.S. Eliot's The Waste Land'.

\section{What is Metaphor?}

Of rhetorical means, metaphor has an intrinsic value in language use that one cannot imagine any language without metaphors. Lakoff \& Johnson (2003, p. 4) go so far as to envisage metaphor as part of the conceptual system of language users. They state: "Metaphor is pervasive in everyday life, not just in language but in thought and action. Our ordinary conceptual system, in terms of which we both think and act, is fundamentally metaphorical in nature". Moreover, metaphor is an important omnipresent phenomenon; for example, a study by Steen et al. (2010, pp. 765-796) shows that nearly one in about every seven and a half lexical units in the British National Corpus is related to a metaphorical mapping structure.

Present-day dictionaries such as the Online Oxford English Dictionary, the Online Webster's New World College Dictionary and the Online Longman English Dictionary have almost similar definitions of metaphor. They share the idea that metaphor is a figure of speech in which a word or a phrase is used to compare two unlike objects, ideas, thoughts or feelings in order to provide a clearer description. For example "he is a lion in a battle", "an icy glance" and "nerves of steel". Newmark (1988, p. 104) argues that "metaphor could be any figurative speech: the transferred sense of a physical word; the personification of an abstraction; the application of a word or collocation to what it does not literally denote, i.e., to describe one thing in terms of another". Simply it can be said that a metaphor is a way of depicting something by calling it something else. It is not only a core concept in literary studies, but also a prevalent companion in everyday language.

\subsection{Functions of Metaphor}

Newmark (1988, p. 104) believes that metaphors have two functions: the first is the rhetorical function, whilst the second is the cognitive function. The two functions may be called content and form. On the one hand, metaphor, as a significant rhetorical tool, is used to make a comparison between two different concepts or things that share a feature or a property in order to reveal the senses. Metaphor is considered as a decorative addition to the ordinary plain speech. It is also used at certain times to achieve aesthetic effects.

Metaphor is considered an important tool for poets to express emotions, believes and ideas in other simpler terms beside helping to decorate verses. In addition, metaphor is employed as a tool to clarify meaning, or to make the statement more vivid. It is also used as a way of shocking or conceit people. (Newmark, 1981, p. 84)

\section{What is Pessimism?}

Pessimism is the inclination of seeing, expecting, or confirming the darker aspects of a situation or the evil and unfavorable results, events, troubles, etc. It is also believing that the present world is the most horrible and everything tends to wickedness. Moreover it can be defined as the principle that the evilness and hurt in life are not recompensed by righteousness and gladness. (www.blog.talkingphilosophy.com/?p=1845) 
It is an idea that all things naturally tend to evil, things are generally bad, world is the worst of all possible worlds, it is the tenet that the evil in life exceeds the welfare, the inclination to see, expect, or affirm only bad or unfavorable results, outcomes, situations, troubles, etc. (www.dictionary.com/browse/pessimism)

Simply, it can be said that pessimism means expecting obstacles, bad results or outcomes. It may also mean believing or feeling helpless or powerless and looking to the black side of life focusing on the glass half empty.

This part of the research consists of sections on who is Eliot, why The Waste Land was chosen to be the material of the study, strategies of using metaphor as a means of pessimism as well as the practical analysis of selected excerpts from each division of the poem.

\section{Eliot's Life}

First of all, Eliot was chosen from an enormous group of famous poets because of his style is distinguished as a poet and a critic that he mesmerized not only audience of readers but also poets and critics of English and different languages.

Thomas Stearns Eliot, often shorten as T. S. Eliot, was born on September 26, 1888 in St. Louis, Missouri, USA, and died on January 41965 in Kensington, London, England, at the age of 76. He studied at Harvard University and had the bachelor degree in 1909. In 1910, he earned his Master degree and then, settled in Paris continuing his study at the Sorbonne. As he was a chronic smoker, Eliot had a serious medical condition in his lung which caused him health problems. He stayed suffering in a hospital in London for some time till he passed away on January 4, 1965. (Bush, 1991, p. 72)

Eliot was one of the most successful twentieth-century poets, essayists, dramatists, publishers, playwrights and literary and social critics. He became famous mainly for his poems like "The Waste Land", "The Love Song of J. Alfred Prufrock", "The Hollow Men", "Ash Wednesday and Four Quarters". In addition to poetry, Eliot wrote some fine plays, the best of which are The Rocks and Murder in the Cathedral. (Worthen, 2009, p. 32).

His extensive fame came by his distinguished seven plays, including "Murder in the Cathedral" (1935). He received the Nobel Prize of Literature for his outstanding works of literature in 1948, particularly for his wonderful, matchless contribution to modern poetry. His most well-known essay is "Tradition and the Individual Talent". He also was distinctive in the field of literary criticism and has been considered the greatest literary critic of the 20th century, (ibid).

Eliot lived in a period filled of disturbances and conflicts that affected not only people and countries in Europe but also the whole world. Surely, literature generally and poetry particularly were affected by those circumstances. The world had been suffering for decades because of The World War I and II. Indisputably, such bloody and gloomy events steered Eliot's pen toward pessimism.

Eliot as an exceptional poet didn't have exceptional life, he was Educational and talented, he never lived poverty since he belonged to an elite family which was very rich, religious and educated.

Talented conservative Eliot whose mother was a poet and father was a businessman, lived a luxury life in a rich educated religious family. By his new style, Eliot created a renewal storm in English and the world poetry. Approximately twenty books have been left by him in criticism and poetry.

\subsection{Why Was Eliot Pessimist in His Great Waste Land?}

To achieve equilibrium that drives the wheel of life forward, it is necessary for man to interact with human interactions properly that indicates a man's ability to adapt to the circumstances surrounding him. In fact, no human is born pessimist naturally so pessimism is something acquired not inborn. The pessimist have their own convictions that were affected by environmental, political, social.... factors, such convections steer their minds to expect the worst or convinced things to be gloomy.

Eliot lived in an era full of turmoil and major events in the history of Europe and the world, especially between The World War I and II. As all people in Europe, Eliot and so his poetry suffered from the misery, squalor, melancholy, great sadness, pain of bodies, thirst of souls and demise of beauty.

It is obvious that living in a period and a place of a great war strongly affects writers orientations. Wars always encase literature by a melancholic wrap creating an atmosphere of awkwardness and ticklish in the mind of the writer. So Eliot in his Waste Land, draws veritable picture for life in Europe in the aftermath of World War I (1914-1918). He depicts life in a fantastic new way displaying the real effects of the war like poverty, sickness, crime, killing, robbery, Lack of security, etc. The negative effects of the war created an ambience of misfortune lasted for decades, such conditions compelled Eliot and other writers to dye their works by pessimism in which their hopelessness infiltrated to literature expelling ambition and killing hope. 


\subsection{The Waste Land}

There is no doubt that The Waste Land is one of the most important poems if not the most in the twentieth century. Actually, it is the greatest longest, most masterful, most convoluted, and most pretentious poem that T.S. Eliot ever composed. He spent two years to finish writing this marvelous poem 1921 to 1922. With its 433 lines, it is considered a very long poem comparing to the American and British poems in the 20th century. Eliot divided his Waste Land into five sections and he titled each part. "The Burial of the Dead", "A Game of Chess", "The Fire Sermon", "Death By Water" and "What the Thunder Said"

As an epic ironic poem, The Waste Land is a distinguished attempt representing a reflection of the miserable life of the European community, particularly during and after the World War I. On the one hand, the tone of this poem is hopelessness which is a creative transformation of the horrific circumstances of the Europeans after the great war. Not only the main title and the subtitles imply a melancholy atmosphere where Eliot describes Europe as the Waste Land but it is also clear that most of the verses of the poem pessimistically describe the dejected situations and collapsing culture after The World War I. On the other hand, Eliot rhetorically and skillfully uses metaphor as a means of drawing those pessimistic scenes so it is touched that The Waste Land is heavily pregnant of metaphorical pessimistic expressions where almost each stanza has a taste or a smell of pessimism.

In fact, The Waste Land is considered a cultural document brimming of pessimism and hopelessness of the modern soulless people and the ruined miserable city. The poem has contradictory sounds come from history and myths, some from everyday speech while others from the poet's imagination.

http://www.bachelorandmaster.com/britishandamericanpoetry/the-waste-land.html\#.WRwpyZKGPIU

\section{Methodology}

The present study seeks to investigate using metaphor as an effective means to draw pessimistic images in English poetry after the World War I with reference to T.S Eliot's Waste Land in which Eliot tries to illustrate the tragic circumstances of the European miserable life which control and affect his approach in writing his poetry. To accomplish that, an attempt will be made to collect various metaphorical pessimistic scenes from this poem. After that, the expressions and verses will be analyzed and studied trying to illustrate how metaphor is used by the poet to steer the scenes of the poem. Regarding the data collection, the main concentration is made on T.S. Eliot's Waste Land's metaphorical pessimistic and optimistic expressions. Samples of the pessimistic metaphors are taken and analyzed to show the elements of the metaphor and how metaphor affects the pessimistic image. In addition, all cases of metaphor are counted, analyzed and divided into pessimistic and optimistic, then a comparison is made between them to confirm that Eliot was pessimist in his Waste Land. After that, the percentages are taken out of the statistics to support the results of the study. Finally, results and recommendations are concluded.

\section{The Analysis and Discussion Part}

In this part an attempt is made to evaluate and analyze some verses of many that have metaphorical expressions. Almost every single case of metaphor in the poem is observed, analyzed and studied. It is said that "This is just the tip of the iceberg" so the title "The Waste Land" immediately implies a gloomy impression of an arid desolation which is a pessimistic symbol of the effects of the brutal horrific war. The title takes us to a melancholy atmosphere in the European land which is occupied by physical and spiritual destruction. Here, Eliot metaphorically compares the destroyed Europe land to a desert where man can hardly live, and this image shows us how much the poet is pessimist in his poem.

Carrying on the scene of the title, pessimistically and metaphorically, Eliot starts the preface of the first and longest session by the title "The Burial of the Dead" comparing Europe land to the cemetery and depicting the living Europeans to the burial dead bodies in the cemetery since the living are suffering more than the dead. It is noticed that metaphor is used by the poet to show pessimistic atmosphere of the first session and the whole poem.

Here are some of many metaphorical pessimistic expressions used in The Waste Land.

6.1 The First Case Is Taken from the First Session Includes Lines (1-4):

"APRIL is the cruelest

month, Breeding Lilacs out

of the dead land, mixing

Memory and desire" 
It is clear that the first stanza has some sigh about prewar romance which does not come into view in the rest of the poem. Eliot seems to succumb to despair by regrettably comparing the prewar superb rural life to the current horrifying image after the war which is full of degradation, destruction, decomposition and debilitation. It is noticed that a sea of metaphorical pessimisms about man's current life is clear in this session of the poem.

This example is the personification of April that obviously appeared in the first stanza which contains several metaphors. Eliot, here, confuses the reader by starting the first stanza using metaphorical personification when describing April as the cruelest month of the year. By using such rhetorical image, the poet gives human features to April in order to dramatize its effects upon readers. Moreover, using such metaphor plays a vital role in attracting the readers' attention to a completely unexpected image which is against the real situation. Despite the fact that April, the beginning of spring in Europe, is known as the traditional symbol of rebirth, love, hope, youth, growth, new power, creativity and optimism, Eliot uses it as the worst and cruelest month that renews sorrow, sadness and depression because all of the nice symbols of April disappeared in Europe after the World War I, he also blames this month pessimistically to pass upon Europe though it becomes a dry, poor, barren and waste land after the World War I.

By figuratively asserting that April is the cruelest month, Eliot pessimistically uses the points of comparison between April and a cruel person to convey a pessimistic understanding about the unfavorable emotions and feelings brought to him by this month which is usually a symbol of love, rebirth, spring ... etc.

April is also cruel since it is breeding Lilacs out of the Dead Land; though Lilac, with its purple color is usually the symbol of early love, it is a symbol of death in the Waste Land. April is also the cruelest month because it combines the desire for the fabulous life before the war to the current barren desolation creating a great desire to get rid of these hard circumstances. Eliot believes that the flowers of April have no benefits at all as all people are dead even the living ones who lose their morals and become soulless bodies, so that cruelty and brutality are not linked to death, but to life.

In "mixing memory and desire" Eliot figuratively and metaphorically confirms that April has the ability to mix things, comparing it to a human being who really has the ability of mixing things. On the other hand, memory and desire, which are incorporeal, are compared to corporeal things which can be easily mixed. Eliot is pessimist in this scene which shows the reader that he does not like the painful tragic present showing his desire to return back to the past memory in which life was happier in London. The poet heavily employed metaphor as a means to pigment his poem by pessimistic feelings.

\subsection{The Second Case Which Is from the First Session Has Lines 5 and 6}

"Winter kept us warm, covering

Earth in forgetful snow,"

Eliot reverses the reality of winter in the image "Winter kept us warm", he compares winter to the sun which keeps people warm though it is known that people in Europe live a very cold weather in winter. Nevertheless, pessimistically, he prefers winter because it brings snow covering the features of land and so the gloomy past events. Skillfully, the poet could manipulate these metaphorical expressions to produce delicate rhetorical attractive pessimistic images.

\subsection{Lines 27 to 30 Formulate the Third Case as}

A heap of broken images, where the sun beats,

And the dead tree gives no shelter, ...

And the dry stone no sound of water

I will show you fear in a handful of dust

In this stanza, Eliot metaphorically compares the sun to a person who can beat and the images to one whom is beaten, the broken images are constructing a big pile and the sun beats instead of shines. The expression "A heap of broken images" is a sign that man's grasp of life is damaged so he cannot recognize the reality of things. In the metaphorical expression "And the dead tree gives no shelter ..." tree and stone are compared to man who has the ability to give things. This scene probably means that the still living people are dead though they seem alive, they are soulless living bodies because of the absence of morals and happiness. Furthermore "No sound of water" possibly means that the European person is thirsty for the prewar cheerful life and he is now dying of spiritual thirst. Finally, in the verse "I will show you fear in a handful of dust" Eliot prefers death to get rid of his tragic life, besides that death is the fate of all people and each person must pass away one day and he/ she will ultimately be a handful of dust then. Pessimistically and metaphorically Eliot embodies the incorporeal unseen 
fear of death to a seen tangible physical thing which may mean that the sand of European land is heavily mixed with a lot of blood and it is pregnant of too many bodies.

\subsection{Extracted from Line 30, the Fourth Case Is}

"I will show you fear in a handful of dust."

In this scene Eliot metaphorically compares fear, which is incorporeal and unseen, to a seed which is physical and visible. In this image, Eliot is talking about a natural human feeling which is fear from death. Actually, he claims he will show fear from death which is invisible in a handful of dust referring to the dead body when it decays to soil. Pessimistically, Eliot says that the dust of London has become a symbol of fear because it is satiated by blood and corpses by the war.

Religiously, Eliot refers to what is mentioned in the Bible about Man's originating from ashes and dust and returning to ashes and dust. In this sense, dust refers to the death of the earthly body, and the fear of death transfers clearly to the mind of the reader in a handful of dust.

\subsection{Lines 60 to 63 Have the Fifth Case as}

Unreal City,

Under the brown fog of a winter dawn, ...

A crowd flowed over London Bridge, so many,

I had not thought death had undone so many, ...

Obviously, the soul of pessimism appears when the poet is despair over London which is "Unreal city" embodied as "The Waste land" where sad London is full of bodies, crimes, desolation, etc. This sorrowful view shows that Eliot is desperate as he is an unlucky observer of such depressed situations. Eliot likens the land destruction by the war which hides its features to the fog that does so, He also depicts the fog as brown referring to the heavy dust occurring during bombing and destructing. Moreover, Eliot borrowed the gloomy image of "A crowd flowed over London Bridge, so many" from a custom during the reign of Elizabeth in which the heads of criminals were cut off and hanged on the London Bridge to be as a lesson and warning for others cautioning them from committing such crimes, so Eliot refers not only to mournful living people but to the spirits of millions who were widely killed before. What is more, the poet in this scene metaphorically compares the crowd of people's spirits move over the bridge to the waves of the sea.

http://thewastelandtseliotela30nisbet.weebly.com/i-the-burial-of-the-dead.html

6.6 Taken from Lines 71 to 77 Forming the Sixth Case Some Metaphors Are Discussed Here

"That corpse you planted

last year in your garden,

Has it begun to sprout?

Will it bloom this year?

has the sudden frost

disturbed its bed?"

Showing his deep sadness in this image, Eliot is talking about the body of his close dead friend Jan Ferdinand. He compares his friend's corpse which is buried underground to a planted seed which will grow one day. He also compares the frost and the bed to persons who has real feelings.

By using several metaphors in one pessimistic image, Eliot mesmerizes the readers where he could personify each of the body, the frost and the bed when he compares each of them to a living person that could grow, disturb or be disturbed. Eliot, in this metaphorical pessimistic expression, expertly and rhetorically plays with words to show the reader his sadness of losing his friend and his logging to meet him.

The second section of the poem is metaphorically called "A Game of Chess" which pessimistically depicts postwar life as a game of chess where the hard board of chess is the waste land. Metaphorically, he compares solid, tough and soulless Europe land to the board of chess in which both of them have spiritless inanimate bodies, moreover, the chess stones are symbols of the living people whose life is devoid of love and feeling, soulless, motionless and deceased, moreover they have blind eyes, deaf ears and mindless heads. They are controlled by their lusts destroying each other and occupying each other's land brutally and savagely. Also, metaphorically Eliot describes people while waiting their bleak fate on London bridge as the stone of chess 
which are waiting the players to move them to a vague destiny without any volition, they are indeed neither defunct nor living. So chess is the real, substantial and typical game of The Waste Land where the relationships in the society are not more than movements on the board of chess.

6.7 The Seventh Case Is in Lines 83 to 86 Where Several Metaphors Give a Pessimistic Picture of the Miserable Life in Europe as

"and upside down in air were towers

Tolling reminiscent bells, that kept the hours

And voices singing out of empty cisterns

and exhausted wells"

In this scene which is taken from the fourth session Eliot fascinates the readers by using some metaphors in picturing the misery life and the dismal situations in London where the destructed towers are still tolling the memorial bells which stop time referring to where time is passing very slow. In this pessimistic scene the poet compares the towers to people who have the ability to toll bells, beside that he compares bells to people who can keep things and hours which are incorporeal to corporeal things. In the third verse he personifies cisterns and wells when he compares the cistern and well to a person who can sing. Moreover Eliot in the "exhausted wells" compares the depleted wells to workers who are very tired after finishing a very hard work depicting the regrettable circumstances and how much people were suffering from the war.

6.8 From the Fire Sermon, Lines 173 to 175 Are the Eighth Case

"The river's tent is broken, the last fingers

of leaf Clutch and sink into the wet bank.

The wind Crosses the brown land, unheard."

In this scene, which is taken from the third session "The Fire Sermon", the poet sadly compares the situations of the river before and after World War I. He bemoans the magnificent beautiful condition of River Thames before the war. There are sweet water, nymphs (young women), cool shade, a lot of green bushy trees create a tent over the river, and the trees' fallen leaves ornament parts of the river. In contrast of that nice image, the war distorted everything in which water becomes dirty, the nymphs depart, there are few leafless trees and so little shade and instead of the trees' leaves, there are many used cans and bottles on the surface of the river. Moreover, the river is polluted by waste water coming from a gas factory which was built for the war on the side of the river. In this image "The river's tent is broken", Eliot personifies of the river to a person who is happy of owning a tent, he also compares the bushy trees to a tent, he also compares trees with their broken leaves in water to people who have fingers; using these metaphorical expressions he shows the reader the clear pessimistic circumstances for not only people but also for the river and its trees.

The following tables compare the frequency and the percentage of metaphors to the whole verses of the poem, in addition to comparing the pessimistic and optimistic metaphors to the total cases.

Table 1. The total number of the verses of The Waste Land and the frequent of metaphor in addition to the percentage

\begin{tabular}{lll}
\hline Number of verses & 433 & $100 \%$ \\
\hline Number of metaphors & 180 & $42 \%$ \\
\hline
\end{tabular}

Table 1 illustrates that the total number of metaphors used in the poem is 180 cases of 433 verses, which means around $42 \%$. Furthermore, the analysis reveals that each of 2.40 verses of The Waste Land have at least one metaphor which emphasizes the significance of using metaphor in poetry generally and in Eliot's Waste Land particularly. 
Table 2. Contrasting the number and percentage of the optimistic and pessimistic metaphors to the total 180 metaphors used in poem

\begin{tabular}{lll}
\hline Number of metaphors & 180 & $100 \%$ \\
\hline Pessimistic metaphors & 155 & $86 \%$ \\
Optimistic metaphors & 25 & $14 \%$ \\
\hline
\end{tabular}

Of the 180 metaphors, the pessimistic metaphorical expressions are 155 cases which means $86 \%$, while the optimistic ones are not more than 25 cases forming $14 \%$ only.

The analysis clearly demonstrates and proves that The Waste Land is a pessimistic poem where metaphor is influentially used as a means of pessimism which formulates a glum atmosphere in the poem. In addition, few glimpses of optimism are used which are not competent among the gigantic army of pessimistic metaphors. Nevertheless, using such optimistic allusions could mean that along with every adversity is relief, so it can be said that Eliot is not entirely pessimistic in his Waste Land.

\section{Findings and the Answers of the Study Questions}

It is discovered that metaphor is one of the most vital and effective means to depict pessimistic scenes in English poetic style. However, Eliot as an American British poet heavily used metaphor drawing many pessimistic views in his Waste Land in addition to using it as a means of optimism sometimes. Moreover, the study shows that Eliot tries to summarize the events, reasons and results of the cultural and spiritual death of the modern society in Europe after the World War I.

The Main three questions of the study are answered as a conclusion of the study:

1). How frequent are metaphorical expressions used in The Waste Land?

The study shows that metaphorical expressions are heavily used by Eliot in his 433 line Waste Land. It is revealed that The Waste Land is profusely planted of metaphors, and this puts emphasis on the significance of using metaphor in English poetry generally and Eliot's particularly.

2). Does Eliot use metaphor as a means of pessimism?

Doughtily, metaphor is profoundly used as a powerful tool in translating the affliction and suffering of both the society and the poet himself in a poetic epic form. The analysis reveals that most of the Waste Land's metaphor cases are pessimistic demonstrating that the poet used metaphor as an effective means of pessimism. Nevertheless, it is revealed that there are some optimistic metaphorical expression used by Eliot which proves that he is not completely pessimist in his poem.

3). Is metaphor an effective rhetorical factor in constructing popular pessimistic poems as The Waste Land?

It is hardly finding a stanza of any pessimistic poem without a metaphor or more. In fact, no one can imagine the proportion of dilapidation and decay of The Waste Land or any other pessimistic poem without its metaphors. If not the best, it can be said that metaphor is a very effective rhetorical means in composing pessimistic images in English poetry.

\section{References}

Bush, R. (1991). T.S. Eliot: The Modernist in History. New York: Pergamum Press.

Cap, P., \& Okulska, U. (Eds.). (2013). Analyzing genres in political communication: theory and practice (Vol. 50). Amsterdam: John Benjamins Publishing.

http://thewastelandtseliotela30nisbet.weebly.com/i-the-burial-of- the-dead.html

http://www.bachelorandmaster.com/britishandamericanpoetry/the-waste-land.html\#.WRwpyZKGPIU

Kazemian, B., \& Hashemi, S. (2014). Critical discourse analysis of Barack Obama's 2012 speeches: Views from systemic functional linguistics and rhetoric. Theory and Practice in Language Studies (TPLS), 4(6), 1178-1187.

Kazemian, B., \& Hashemi, S. (2014). Nominalizations in scientific and political genres: A systemic functional linguistics perspective. International Journal of Humanities and Social Sciences (IJHSS), 3(2), 211-228.

Kazemian, B., \& Hashemi, S. (2017). A Radical Shift to a Profound and Rigorous Investigation in Political Discourse: An Integrated Approach. International Journal of English Linguistics, 7(3), 115-128. https://doi.org/10.5539/ijel.v7n3p115 
Kazemian, B., Behnam, B., \& Ghafoori, N. (2013). Ideational grammatical metaphor in scientific texts: a Hallidayan perspective. International Journal of Linguistics, 4(4), 146-168.

Lakoff, G., \& Johnson, M. (2003). Metaphors We Live By. London: The University of Chicago Press.

Mason, J. (2017). Is it Rational to be Optimistic or Pessimistic?. Retrieved from http://blog.talkingphilosophy.com/?p=1845

Newmark, P. (1981). Approaches to Translation. New York: Pergamum Press.

Newmark, P. (1988). A Textbook of Translation. London: Prentice hall International (UK) Ltd.

Noor, M., Ali, M., Muhabat, F., \& Kazemian, B. (2015). Systemic Functional Linguistics Mood Analysis of the Last Address of the Holy Prophet (PBUH). International Journal of Language and Linguistics, 4(1-1), 1-9. Special Issue: Critical Discourse Analysis, Rhetoric, and Grammatical metaphor in Political and Advertisement Discourses.

Steen, G. J. et al. (2010). Metaphor in usage, Cognitive Linguistics, 21(4).

Worthen, J. (2009). T.S. Eliot: A Short Biography. London: Haus Publishing.

www.dictionary.com/browse/pessimism

Zhou, Q., \& Kazemian, B. (2015). A Rhetorical Identification Analysis of English Political public Speaking: John F. Kennedy's Inaugural Address. International Journal of Language and Linguistics, 4(1-1), 10-16. Special Issue: Critical Discourse Analysis, Rhetoric, and Grammatical Metaphor in Political and Advertisement Discourses.

\section{Copyrights}

Copyright for this article is retained by the author(s), with first publication rights granted to the journal.

This is an open-access article distributed under the terms and conditions of the Creative Commons Attribution license (http://creativecommons.org/licenses/by/4.0/). 